\title{
Hyles svetlana Shovkoon, 2010 (Lepidoptera: Sphingidae) - new species for Mongolian fauna and new records of Hawk-moths in Western Mongolia
}

\author{
Hyles svetlana Shovkoon, 2010 (Lepidoptera: Sphingidae) - \\ новый вид монгольской фауны и новые находки бражкников \\ в Западной Монголии
}

\author{
R.V. Yakovlev ${ }^{1,2}$, V.V. Doroshkin ${ }^{3}$ \\ P.B. Яковлев ${ }^{1,2}$, В.В. Аорошкин ${ }^{3}$
}

\footnotetext{
1 Altai State University, Lenina 61, 656049 Barnaul, Russia. E-mail: yakovlev_asu@mail.ru

2 Tomsk State University, Laboratory of Biodiversity and Ecology, Lenina pr. 36, 634050 Tomsk, Russia.

${ }^{3}$ Chelyabinsk, Brat'ev Kashirinykh str., 151-49, 454004 Russia. E-mail: ural@kros-china.ru

${ }^{1}$ Алтайский государственный университет, пр. Ленина 61, Барнаул, 656049 Россия.

2 Томский государственный университет, Лаборатория биоразнообразия и экологии, пр. Ленина 36, Томск, 634050 Россия.

3 ул. Братьев Кашириных 151-49, Челябинск, 454004 Россия.
}

KEY WORDS: Sphingidae, Mongolia, Hyles svetlana, new record.

КЛЮЧЕВЫЕ СЛОВА: Sphingidae, Монголия, Hyles svetlana, новая находка.

ABSTRACT. In south-western Mongolia we discovered a species new for the Mongolian fauna, Hyles svetlana Shovkoon, 2010 (Lepidoptera, Sphingidae). We also present new localities of Sphingidae collectied in western Mongolia (southern portion of Dzhungarian Gobi, ridges Baitag-Bogdo, Ikh-Khavtag-Ula and Zhargalant-Khairkhan).

РЕЗЮМЕ. В юго-западной Монголии обнаружен новый вид для монгольской фауны - Hyles svetlana Shovkoon, 2010 (Lepidoptera, Sphingidae). Приведены новые локалитеты для бражников, собранных в Западной Монголии (южная часть Джунгарской Гоби, хребты Байтаг-Богдо, Их-Хавтаг-Ула и Жаргалант-Хайирхан).

\section{Introduction}

The sphinx-moths of Mongolia are relatively well studied [Derzhavets, 1977; Yakovlev, Doroshkin, 2004; Yakovlev et al., 2015]. But several regions of Mongolia are studied very poorly from an entomological point of view. To fill these gaps, in 2015, R.V. Yakovlev organized 2 expeditions (the first - in the end of May beginning of June, the second - in July). The main aims were to study insects in the southern portion of Dzhungarian Gobi, two ridges of the Dzhungarian border (Baitag-Bogdo and Ikh-Khavtag-Ula) and the ridge Zhargalant-Khairkhan. During the expedition we collected Sphingidae, the localities of which are provided below, and we also discovered a species new for the Mongolian fauna, Hyles svetlana Shovkoon, 2010.
Material and methods

The adult Sphingidae were collected using the combined light lamp Phillips-250 W mounted above the fabric screen, battery light traps with the lamp Philips TL 8W/05 and chloroform as the killing agent. The collected material is deposited in the private collections of the first and second authors.

\section{Results}

In the new localities (Figs 1-4) we collected 10 species of Sphingidae. The list is provided here.

\section{Sphinx ligustri Linnaeus, 1758}

MATERIAL EXAMINED. 1 \%, SW Mongolia, Hovd Aimak, Bajtag-Bogd-Uul Mts., Baruun-Khargaityn-Gol river Valley (4516'N; 9057'E), 1900-2000 m, 18-21.05.2015, leg. R. \& A. Yakovlev.

Hyles hippophaes (Esper, 1789)

MATERIAL EXAMINED. $2 \sigma^{\top} \sigma^{\top}$, W Mongolia, Hovd Aimak, Dzun-Dzhargalant-Khairkhan, Ar-Shatyn-Gol river Valley $\left(47^{\circ} 44^{\prime} \mathrm{N}\right.$; $\left.92^{\circ} 27^{\prime} \mathrm{E}\right), 2100 \mathrm{~m}, 03.06 .2015$., leg. R. \& A. Yakovlev.

Hyles chamyla (Denso, 1913)

MATERIAL EXAMINED. $3 \sigma^{7} \sigma^{7}$, SW Mongolia, Hovd Aim-

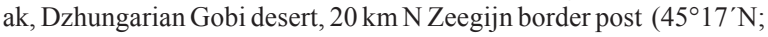
$\left.92^{\circ} 09^{\prime} \mathrm{E}\right), \mathrm{h}=1400 \mathrm{~m}, 29-30.06 .2015$, leg. R. Yakovlev.

\section{Hyles gallii (Rottemburg, 1775)}

MATERIAL EXAMINED. $1 \sigma^{7}$, W Mongolia, Hovd Aimak, Dzun-Dzhargalant-Khairkhan, Ar-Shatyn-Gol river Valley $\left(47^{\circ} 44^{\prime} \mathrm{N}\right.$; $\left.92^{\circ} 27^{\prime} \mathrm{E}\right), 2130 \mathrm{~m}, 26.06 .2015$., leg. R. Yakovlev; $1 \mathrm{O}^{7}$, SW Mongolia, Hovd Aimak, Bajtag-Bogd-Uul Mts., Baruun-Khargaityn-Gol 


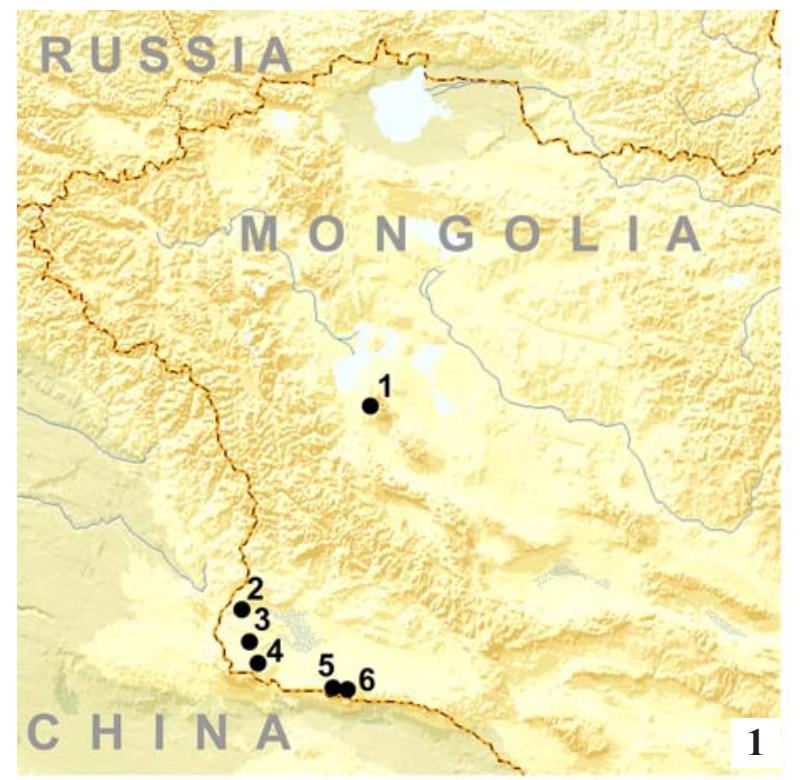

1 - Dzun-Dzhargalant-Khairkhan, Ar-Shatyn-Gol river Valley $\left(47^{\circ} 44^{\prime} \mathrm{N} ; 92^{\circ} 27^{\prime} \mathrm{E}\right) ; 2$ - Dzhungarian Gobi desert, Uvkhod-Ula

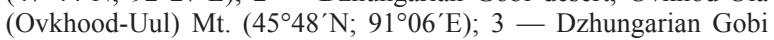
desert, $20 \mathrm{~km} \mathrm{~N}$ Zeegijn border post $\left(45^{\circ} 17^{\prime} \mathrm{N}\right.$; 92 $\left.09^{\circ} \mathrm{E}\right) ; 4$ Bajtag-Bogd-Uul Mts., Baruun-Khargaityn-Gol river Valley $\left(45^{\circ} 16^{\prime} \mathrm{N}\right.$; $\left.90^{\circ} 57^{\prime} \mathrm{E}\right)$; 5 - Ikh-Khavtag-Uul Mts., near YargajtynSajr gorge ( $45^{\circ} 03^{\prime} \mathrm{N}$; $\left.92^{\circ} 09^{\prime} \mathrm{E}\right)$; 6 - Ikh-Khavtag-Nuruu Mts., near Zhugentijn spring, $\left(45^{\circ} 04^{\prime} \mathrm{N}\right.$; $\left.92^{\circ} 12^{\prime} \mathrm{E}\right)$.
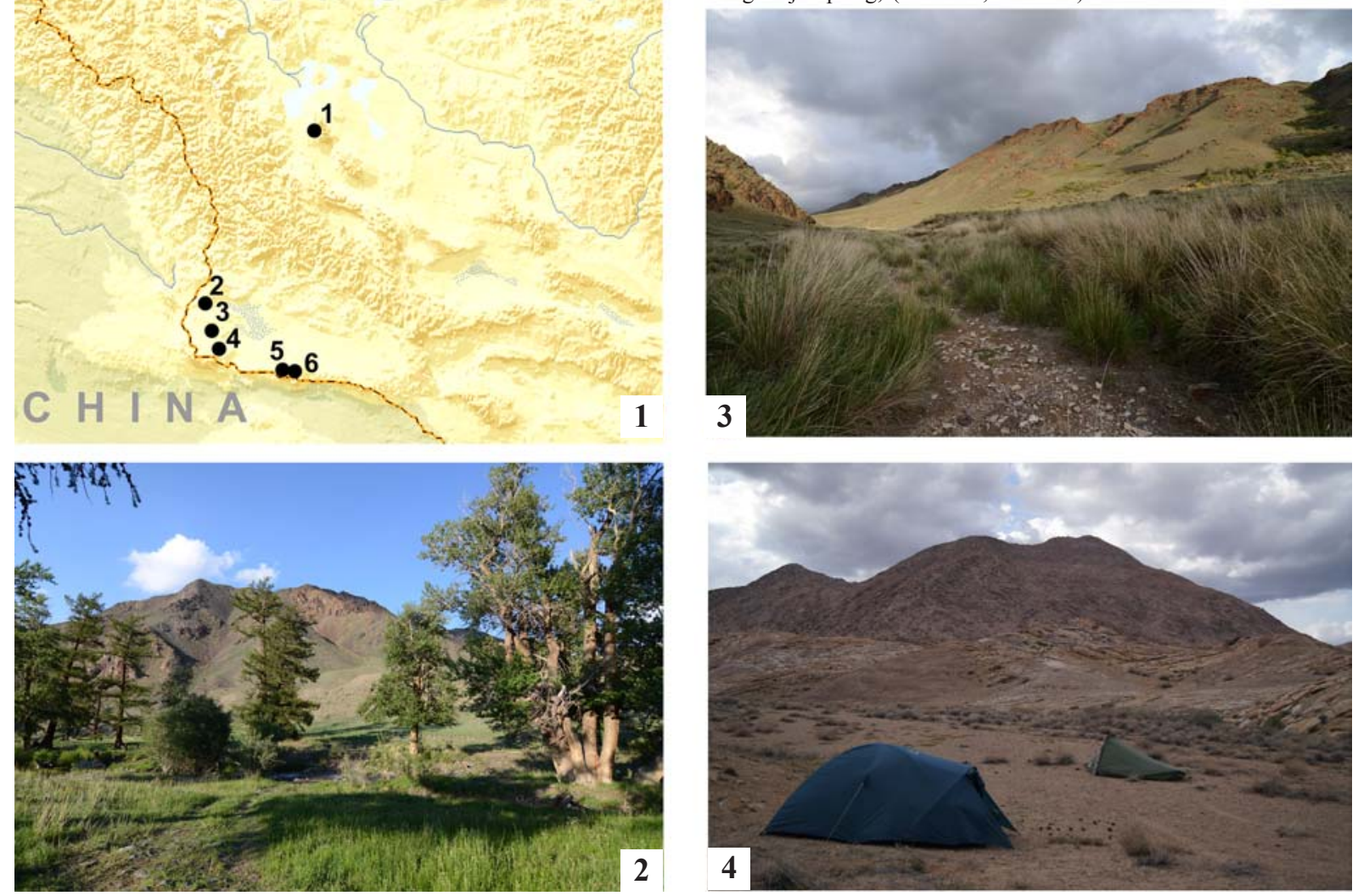

Fig. 1. Map of collecting localities in Hovd Aimak.

Fig. 2. Bajtag-Bogd-Uul Mts., Baruun-Khargaityn-Gol river Valley $\left(45^{\circ} 16^{\prime} \mathrm{N} ; 90^{\circ} 57^{\prime} \mathrm{E}\right)$ (photo by P. Kosachev).

Fig. 3. Ikh-Khavtag-Nuruu Mts., near Zhugentijn spring, $\left(45^{\circ} 04^{\prime} \mathrm{N} ; 9^{\circ} 12^{\prime} \mathrm{E}\right)$ (photo by P. Kosachev)

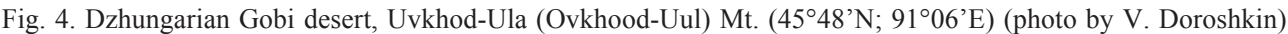

river Valley $\left(45^{\circ} 16^{\prime} \mathrm{N} ; 90^{\circ} 57^{\prime} \mathrm{E}\right), 2000 \mathrm{~m}, 3-5.07 .2015$, leg. R. Yakovlev; $1 \mathrm{~m}, \mathrm{SW}$ Mongolia, Hovd Aimak, Ikh-Khavtag-Nuruu Mts., near Zhugentijn spring, $\left(45^{\circ} 04^{\prime} \mathrm{N} ; 92^{\circ} 12^{\prime} \mathrm{E}\right), \mathrm{h}=2050 \mathrm{~m}$, 30.06-02.07.2015, leg. R. Yakovlev

Hyles costata (Nordmann, 1851)

MATERIAL EXAMINED. 5 O $^{7} \sigma^{7}$, W Mongolia, Hovd Aimak, Dzun-Dzhargalant-Khairkhan, Ar-Shatyn-Gol river Valley $\left(47^{\circ} 44^{\prime} \mathrm{N}\right.$; $\left.92^{\circ} 27^{\prime} \mathrm{E}\right), 2130 \mathrm{~m}, 26.06 .2015 .$, leg. R. Yakovlev.

Hyles churkini Saldaitis \& Ivinskis, 2006

MATERIAL EXAMINED. $1 \sigma^{7}$, SW Mongolia, Hovd Aimak, Ikh-Khavtag-Uul Mts., near Yargajtyn-Sajr gorge $\left(45^{\circ} 03^{\prime} \mathrm{N}\right.$; 9209’E), 1900-2150, 30-31.05.2015, leg. R. \& A. Yakovlev; 3 $\mathrm{O}^{7} \mathrm{O}^{7}$, SW Mongolia, Hovd Aimak, Dzhungarian Gobi desert, $20 \mathrm{~km}$ $\mathrm{N}$ Zeegijn border post $\left(45^{\circ} 17^{\prime} \mathrm{N} ; 9^{\circ} 09^{\prime} \mathrm{E}\right), \mathrm{h}=1400 \mathrm{~m}, 29$ 30.06.2015, leg. R. Yakovlev.

\section{Hyles nicaea (Prunner, 1798)}

MATERIAL EXAMINED. $1 \sigma^{7}$, SW Mongolia, Hovd Aimak, Ikh-Khavtag-Nuruu Mts., near Zhugentijn spring, $\left(45^{\circ} 04^{\prime} \mathrm{N}\right.$; $\left.92^{\circ} 12^{\prime} \mathrm{E}\right), \mathrm{h}=2050 \mathrm{~m}, 30.06-02.07 .2015$, leg. R. Yakovlev; $1 \mathrm{o}^{\prime}$, SW Mongolia, Hovd Aimak, Bajtag-Bogd-Uul Mts., Baruun-Khargaityn-Gol river Valley $\left(45^{\circ} 16^{\prime} \mathrm{N} ; 90^{\circ} 57^{\prime} \mathrm{E}\right), 2000 \mathrm{~m}, 3-5.07 .2015$, leg. R. Yakovlev.

\section{Hyles livornica (Esper, 1780)}

MATERIAL EXAMINED. $1 \mathrm{O}^{7}$, SW Mongolia, Hovd Aimak, Dzhungarian Gobi desert, Uvkhod-Ula (Ovkhood-Uul) Mt. $\left(45^{\circ} 48^{\prime} \mathrm{N}\right.$; $\left.91^{\circ} 06^{\prime} \mathrm{E}\right), 1250 \mathrm{~m}, 26-27.05 .2015$, leg. R. \& A. Yakovlev

\section{Hyles svetlana Shovkoon, 2010}

Figs 5-6

MATERIAL EXAMINED. 1 \% SW Mongolia, Hovd Aimak, Bajtag-Bogd-Uul Mts., Baruun-Khargaityn-Gol river Valley

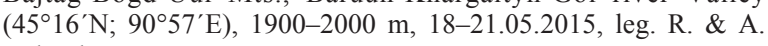
Yakovlev.

COMMENT. Hyles siehei svetlana Shovkoon, 2010 (Lepidoptera, Sphingidae) was described based on a series from south-western Kazakhstan (Aktobe, Qyzylorda, Mangistau regions) (type locality — "Kazakhstan, Aktobe Region, Plateau Shagyray") [Shovkoon, 2010]. The localities of SE Kazakhstan (Alma-Ata region), S. Uzbekistan and $\mathrm{N}$. Turkmenistan were not included into the type series, however they were mentioned in the article. Minor facts on the distribution and food plants (Eremurus inderiensis (Steven) Regel; Asphodelaceae) for this taxon are given in the subsequent works of the author [Shovkoon, 2011, 2015]. 
Later, de Freina and Geck [2014] convincingly demonstrated the species status of the taxon svetlana Shovkoon, 2010. A summary on the species distribution is provided by Pittaway and Kitching [2016].

One female specimen was collected in the light trap. It was the first discovery of this species in Mongolian territory. We can suppose that this species inhabits the territory of China (Fig. 7). We note that species of the genus
Eremurus M.B. are not listed for Mongolia [Gubanov, 1996; Urgamal et al., 2014], however E. inderiensis was indicated in several localities of Chinese Dzhungaria [Grubov, Egorova, 1977]: between Guchen and Beidaotsyao, road from Savan to Paotay, left bank of Urungu river (25 km E Dinsyan), Sayram-Nor. These results are probably a result of an insufficient study of flora in Mongolian border regions.
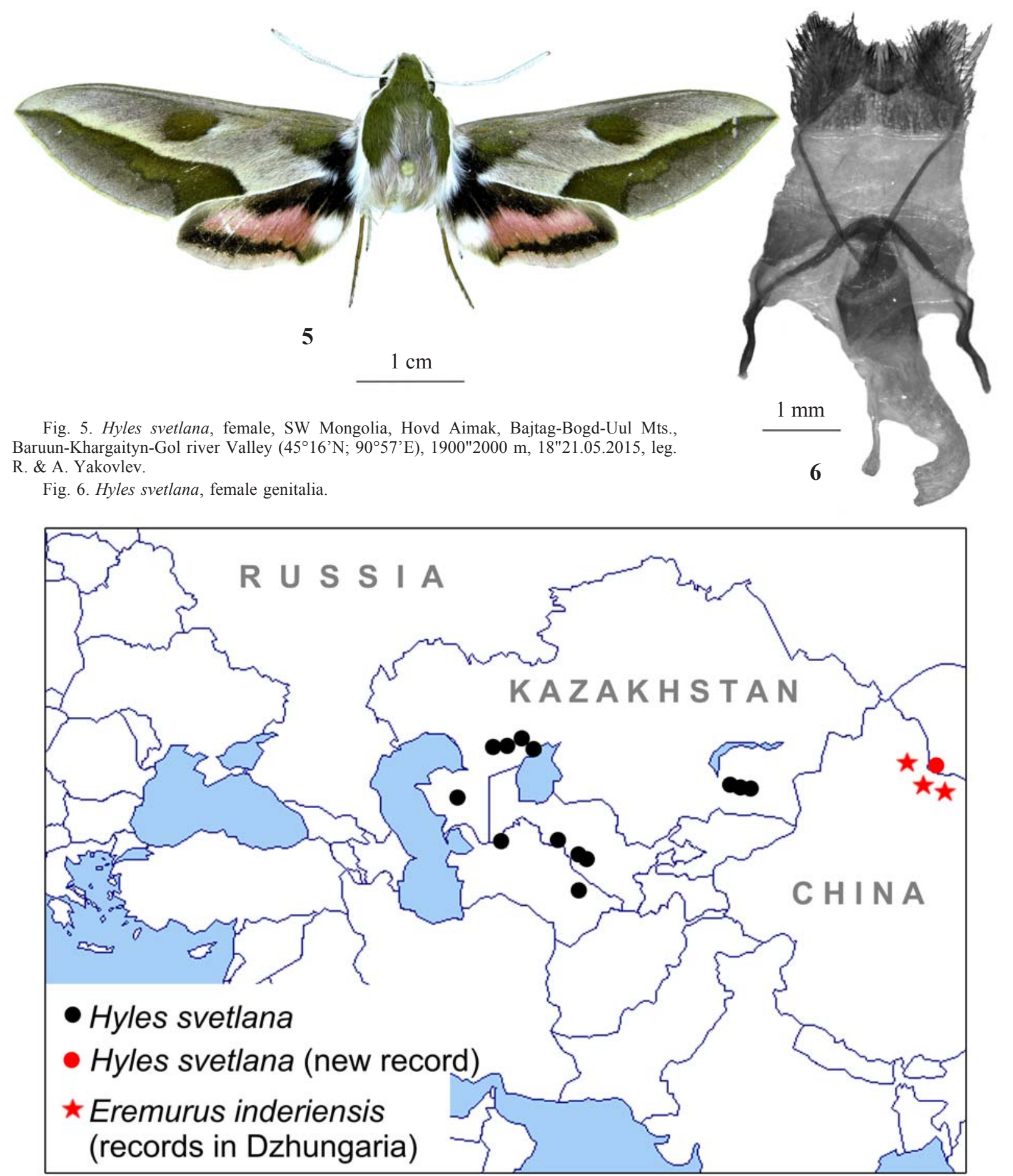

Fig. 7. Map of distribution of Hyles svetlana and north-western Chinese records of Eremurus inderiensis (Steven) Regel (from Pittaway \& Kitching, 2016 with additions). 
Deilephila porcellus (Linnaeus, 1758)

MATERIAL EXAMINED. $2 \sigma^{\top} \sigma^{\top}$, SW Mongolia, Hovd Aimak, Bajtag-Bogd-Uul Mts., Baruun-Khargaityn-Gol river Valley (4516'N; 9057'E), 2000 m, 3-5.07.2015, leg. R. Yakovlev.

The number of Sphingidae species registered in Western Mongolia was increased to 22. The discovery of $H$. svetlana has greatly expanded our understanding of the habitat of this still poorly known species.

ACKNOWLEDGMENTS. The authors are grateful to A.I. Shmakov, P. Kosachev, A. Kechaikin, I. Evdokimov, V. Doroshkin, A. Cherepanov, A. Yakovlev and U. Beket for the assistance in organizing the expedition. The authors are grateful to Anna Ustjuzhanina (Tomsk, Russia) and Eric H. Metzler (USA) for language improvements. We also express our gratitude to D. Shovkoon (Samara) for his assistance in defining Hyles svetlana. The results were obtained within the framework of the state task No. 6.2884.2017/4.6 Ministry of Education and Science of Russian Federation.

\section{References}

Derzhavets Y.A. 1977. [Hawkmoths (Lepidoptera, Sphingidae) of Mongolia] // Nasekomye Mongolii. Vol.5. P.642-648 [in Russian].

Freina J.J. de, Gech M. 2014. Beitrag zur Hyles centralasiae-sieheiArtengruppe. Zur Biologie, Ökologie, Verbreitung und geographischen Variabilität von $H$. siehei (Püngeler, 1903) und Rein- terpretation von Hyles svetlana Shovkoon, 2010 (Lepidoptera: Sphingidae) // Entomologische Zeitschrift. Bd.124. Hf.2. S.6795.

Grubov V.I., Egorova T.I. 1977. [Plantae Asiae Centralis (secus materias Instituti botanici nomine V.L. Komarovii). Fasciculus 7. Liliaceae - Orchidaceae]. Leningrad: Nauka. 138 pp. [in Russian]

Gubanov I.A. 1996. [Conspectus of Flora of Outer Mongolia (Vascular plants)]. Moscow: Valang. 136 pp. [in Russian]

Pittaway A.R., Kitching I.J. 2017. Sphingidae of the Eastern Palaearctic (including Siberia, the Russian Far East, Mongolia, China, Taiwan, the Korean Peninsula and Japan). Available from http://tpittaway.tripod.com/china/a_tob (accessed 2 April 2017).

Shovkoon D.F. 2010 A new subspecies of Hyles siehei (Püngeler) from the deserts of Central Asia (Sphingidae) // Nota lepidopterologica. Vol.33. P.67-79.

Shovkoon D. F. 2011. [The distribution of Sphingidae (Lepidoptera) in the Uralo-Caspian Region] // Entomological and Parasitological Investigations in Volga Region. Collected Proceedings. Vol.9. P.26-35 [in Russian].

Shovkoon D. F. 2015. [On the distribution of hawkmoths in southern Kazakhstan (Lepidoptera, Sphingidae)] // Entomological and Parazitological Investigations in Povolzh'e Region; Collected Proceedings. Vol.12. P.50-55 [in Russian].

Urgamal M., Oyuntsetseg B., Nyambayar D., Dulamsuren Ch. 2014. Conspectus of the vascular plants of Mongolia. Ulaanbaatar: "Admon" Press. 282 pp.

Yakovlev R.V., Doroshkin V.V. 2004. New data of Macrolepidoptera for the fauna of Mongolia. II. (Insecta: Lepidoptera) // Atalanta. Vol.35. Nos3/4. P.390-398.

Yakovlev R.V., Guskova E.V., Doroshkin V.V., Titov S.V. 2015. Sphingidae of the Mongolian Altai (Lepidoptera: Sphingidae) // SHILAP Revista de lepidopterologia. Vol.43. No.171. P.467478. 